\title{
A Theoretical Framework on Reflection in Service Learning: Deepening Reflection Through Identity Development
}

\author{
Toru Kawai * \\ College of Sport and Health Science, Ritsumeikan University, Kusatsu, Japan
}

OPEN ACCESS

Edited by:

Bibiana Regueiro,

University of Santiago de

Compostela, Spain

Reviewed by:

Hamdan Said,

University of Technology

Malaysia, Malaysia

Susan Deeley,

University of Glasgow,

United Kingdom

*Correspondence:

Toru Kawai

kawai-t@fc.ritsumei.ac.jp

Specialty section:

This article was submitted to

Teacher Education,

a section of the journal

Frontiers in Education

Received: 11 September 2020 Accepted: 30 November 2020

Published: 07 January 2021

Citation:

Kawai T (2021) A Theoretical Framework on Reflection in Service

Learning: Deepening Reflection

Through Identity Development.

Front. Educ. 5:604997.

doi: 10.3389/feduc.2020.604997
In higher education, well-designed service learning combines service activities and academic knowledge in reflection, generating essential learning outcomes: academic enhancement, personal growth, and civic engagement. As research on reflection in service learning has shown, the process of reflection deepens through description of service experiences, examination of those experiences and articulation of learning. This article provides a theoretical explanation of deepening the reflection process by incorporating reflection theory and identity theory of college student development, professional development, and general identity development. Expanding the theoretical explanation of the reflective process clarifies the conditions of the deepening student reflection process in service learning in the following ways. First, it focuses on concrete experience then-and-there at that moment rather than abstract impressions by paying attention to personal dissonance in the experience. In addition, it finds discrepancies from differences of views, perspectives, and backgrounds between those of students and others. It connects outward exploration of those differences and inward exploration to construct internal voices toward self-authorship. The deep reflection process requires confronting contradictions through dialogical interplays among the I-positions of their own and others. It bridges discontinuities between past, present, and future selves by expanding the time perspective retrospectively and prospectively, and solving contradictions embedding in their prejudice. Furthermore, it activates plurality in social norms and values. The above conditions should be design principles for deepening critical and dialogical reflection in high-impact service learning. Through deepening reflection in service learning, it can be expected to activate mutuality and support generativity toward solidarity against hostility.

Keywords: reflection, DEAL model, self-authorship, ALACT model, dialogical self theory, identity development 


\section{BACKGROUND AND PURPOSE}

Research findings on service learning have shown that in higher education it has improved student learning outcomes (Eyler and Giles Jr, 1999; Astin et al., 2000; Conway et al., 2009; Celio et al., 2011). In particular, service learning promotes civic engagement and enhances civic attitude, thus playing a role in civic learning in higher education (Bringle and Clayton, 2012; Bringle et al., 2015; Gelmon et al., 2018). Service learning has been established as one of the high impact educational practices in higher education (Kuh, 2008; McCormick et al., 2013).

Research has clarified the learning outcomes that service learning produces, as well as the developmental process that generates those outcomes. One of the central components of this process is reflection, which is defined as "intentional consideration of an experience in light of particular learning objectives" (Hatcher and Bringle, 1997, p. 153). Through reflection, students learn from their social experiences in the community and connect them to academic knowledge (Ash and Clayton, 2009; Kawai and Kimura, 2014).

This paper will expand the theoretical explanation of the relationship between student reflection and outcomes, incorporating reflection theory and identity theory in the broader contexts. It will first provide the review of students' reflection in service learning research, focusing on the model which explains the process for how reflection can generate learning outcomes. It then moves outside the service learning research, to incorporate developmental theory in higher education and professional education. The former, student development theory in college (Evans et al., 2009a; Patton et al., 2016), includes cognitive, intrapersonal, and interpersonal development. Using these theoretical resources enables reinterpretation of the reflection process in service learning and can offer new ways to guide practice and research. Professional education has established the framework of the process of becoming a professional (e.g., teacher, nurse, designer, engineer, lawyer). Research in these areas (Schön, 1983; Korthagen et al., 2001; Benner et al., 2009) recognized these continuous process as making professional identity. Furthermore, based on identity development theory (Schwartz et al., 2011; Côté and Levine, 2014), this article will explain how reflection processes deepen and generate several outcomes and leads to a reinterpretation of the broader relevance of service learning to student development. After focusing on student learning and development, the analysis will discuss the generative character of service learning in relation to society.

\section{HOW DOES REFLECTION WORK: STUDENT REFLECTION FROM SERVICE LEARNING RESEARCH}

The DEAL model for critical reflection consists of three steps with prompts: detailed Description of the service experiences; Examination of those experiences in light of specific educational objectives; and the Articulation of Learning to set goals for improved future action by reexamining the source and contexts of practice (Ash and Clayton, 2009; Whitney and
Clayton, 2011; Jameson et al., 2013; Whitley, 2014). This model focuses on critical reflection, which is a reflective process guided by critical thinking standards (Paul and Elder, 2001). The DEAL model promotes reflective writing and connects service experience with academic knowledge, civic learning, and personal growth. The third step, articulation, expands students' future perspectives, generating personal values, and enhancing civic awareness. Critical reflection examines and questions the contexts surrounding an experience. Contexts are usually taken for granted but they are the stage and matrix from which experiences can emerge (Bateson, 2000). In critical reflection, students confront a series of questions. They specify students' experiences through description and examination: What was the scene? Who was involved? What did he or she think? Why did it happen? Why did he or she do that?

The phase of examining service experience in the model requires students to relate their experiences to educational objectives (Ash et al., 2009). On personal growth, prompts ask students to clarify their strength and weakness. In terms of civic engagement, students examine what they accomplished and alternative ways of approaching their civic activities (e.g., compare and contrast, propose alternative actions, evaluate consequences). For academic enhancement, they reconsider the relevance of and application of academic concepts to their community-based experiences and reinterpret them.

This model uses revised Bloom's taxonomy based on constructive view of learning (Anderson and Krathwohl, 2001) to have students probe the meaning of their experiences. Prompts are designed to orient them to higher order cognitive examination, namely meta cognitive process. Based on description and examination, the articulation of learning inquires into the background of experience, asking how contexts influence events and experience, what kind of factors cause people's behavior or ways of thinking, what values and beliefs enables or constrain their thoughts and behaviors. Engaging service experiences and deepening description and examination on them facilitates students' meaningful articulation of their learning.

Research based on this model with prompts has revealed what kinds of components function in students' reflection through service-learning and how well-instructors facilitate them (Ash et al., 2009; Ash and Clayton, 2009). This model is helpful for designing courses and writing assignments focused on academic learning, civic learning, and personal growth, and for assessing students' reflection. Another study revealed that reflection in service learning not only connects academic learning and service experiences, but also bridges the relationship between curricular or co-curricular learning and extra-curricular experience (Kawai, 2012). It also suggested that reflection can expand beyond the service learning program creating such bridge learning to other disciplinary knowledge, extra-curricular experiences and future purposes (Kawai and Mizokami, 2013; Kawai and Kimura, 2014; Kawai and Moran, 2017). Theoretical explanations on the reflection process need to describe how to deepen this process and generate learning outcomes from the wider perspectives. For this purpose, this article weaves together three threads of theory focusing on reflection and 
identifies the elements of reflective practice in each of the theories connecting to be intrinsic to service-learning practice: student development theory, professional development theory and identity development theory.

\section{DEEPENING REFLECTION FROM DEVELOPMENTAL THEORY IN HIGHER EDUCATION}

Student development theory in college has been expanded, covering multiple domains such as cognitive and epistemological development, ethical development on values and beliefs, social and interpersonal development, and social identity development related to class, race, ethnicity and gender (Evans et al., 2009a; Patton et al., 2016). Fundamental dimensions of student development consists of three dimensions: cognitive, intrapersonal and interpersonal development. In cognitive development, students shift from the dualism where knowledge is right or wrong to a multiplicity of knowledge that accepts diverse opinions and reasons. They then develop an understanding of relativism and commit to relating diverse knowledge from their own perspective and making decisions based on this multiplicity (Perry, 1968; Evans et al., 2009b). In the intrapersonal and interpersonal dimensions, students inquire about their beliefs, values and purposes in life and build relationships of trust with diverse others by broadening their social interactions. Student development theory has conceptualized intrapersonal and interpersonal development as identity development (Chickering and Reisser, 1993). Through differentiating and integrating them in daily experience, students form their identities, which function as a foundation for their daily activities and future orientations (Bronk, 2013; Jones and Abes, 2013; Kawai and Moran, 2017).

The comprehensive perspective on student development has been established as a kind of self-authorship development that synthesizes cognitive, intrapersonal and interpersonal dimensions. Student self-authorship means becoming the authors of their own lives and "the internal capacity to define one's beliefs, identity and social relations" (Baxter Magolda, 2001, p. 269). Self-authorship corresponds to essential learning outcomes (AAC U (Association of American Colleges Universities)., 2007; Baxter Magolda, 2007), which has become embedded in many universities' missions, especially regarding the intellectual development into self-directed learners, selfregulated learners, life-long learners, and critical thinkers (Baxter Magolda, 2001; Ambrose et al., 2010; Nilson, 2013). The development of self-authorship is also related to civic outcomes based on civic engagement toward the betterment of society (Love and Guthrie, 1999; Baxter Magolda and Boes, 2017).

Student development theory of self-authorship is grounded at the junction of the theories of epistemological and intellectual development (Baxter-Magolda, 1992; King and Kitchener, 1994, 2004), and constructive developmental theory elaborated by Kegan (1982). Developmental theory of selfauthorship becomes a holistic view of student development by incorporating constructive developmental theory. From the constructive developmental perspective, the central feature of the developmental process is making meaning, i.e., the way people organize and interpret experiences. For the developmental process, it is not events themselves that are significant but how people make sense of them. The evolution of meaning-making unfolds over time and emerges in more a complex form in three major dimensions: cognitive, intrapersonal and interpersonal (Kegan, 1982, 1994). These three dimensions of development relate to their respective questions: How do I know, who am I, and how do I want to construct relationships with others. Theory on self-authorship expands beyond cognitive development such as reflective judgment and epistemological reflection to intrapersonal and interpersonal development (Baxter Magolda, 2001, 2004). Constructive developmental theory focuses on the subject-object relationship as a key factor for developmental force (Kegan 1982, 1994). The subject represents elements that people cannot sufficiently reflect on, have control over, or be responsible for; if people can do so, this element is an object. The self-authoring mind requires the movement of subject to object by generating internal judgment and personal authority (Kegan and Lahey, 2009).

A large-scale longitudinal interview survey has revealed the multi-faceted phases of the transition toward self-authorship (Baxter Magolda, 2009; Baxter Magolda and King, 2012). The first phase is "following formulas": students follow authority as source of right answers and define their beliefs, values and relationships externally. In this phase, they move from trusting authority to facing tensions with this uncritical trust and recognizing the shortcomings of depending on external authority. Dissonance pushes students to the second phase of "crossroads" where they question external authority, are aware of the need for their internal voices, and further explore ways of constructing them. The process of leaving these crossroads includes listening and cultivating internal voices, and gradually differentiating perspectives of their own and others. In the third phase of "self-authorship," students trust their internal voices, build their internal foundation and secure internal commitments although only a small group of survey participants reach this self-authorship phase.

For diverse students, there are three dimensions of selfauthorship development, i.e., cognitive, intrapersonal and interpersonal dimensions, but there is no consequential sequence to the development of these dimensions and it is not clear which ones trigger development. One illustration describes how dissonance with other students' views in cognitive dimension and interpersonal dimensions provokes intrapersonal exploration for constructing an internal voice (Baxter Magolda, 2004; Baxter Magolda and King, 2012).

The subsequent research provides explanations for several important moments in the shift from external dependent status to internal independent status (Pizzolato, 2007; Barber and King, 2014). Tensions with the external authority one depends upon emerge through contact with new ideas and opinions from other people. The difference brought by other people produces instability and uncertainty into the perspective dependent on external authority. From the viewpoint of the subject-object relationship, the movement from depending on external authority to recognizing the insufficiency of this stance 
is a shift in formula from subject to object. Although the external orientation as a predominant source of defining one's beliefs, identity and relationships is superseded by internal capacity, the external orientation does not disappear but is concomitant and balanced with internal orientation for making meaning. When students who depend on external authority experience discomfort and dissonance persistently, they tend to resolve them by exploring effective resources and support, thus engage in action for constructing internal voices. To rebalance the external and internal orientations, students struggle to reexamine their own prejudices and assumptions.

In the phase of proceeding to self-authorship, students explore and construct their internal voice while continuing their outward exploration. As they question the absoluteness of external authority in entering the crossroads, they probe their assumptions, values, and self-identities in the phase of leaving crossroads and self-authorship. They do not uncritically receive definitions and interpretations of themselves, but critically examine their underlying assumptions, leading to the reconstruction of these interpretations. In the process of constructing their internal voices, students unfold and articulate them gradually: in the earlier phase, an internal voice or sense of self is undifferentiated from themselves; in the later phase, these voices are differentiated into several self-identities and thus take a role of internal foundation for persistent action and commitment. The intrapersonal and interpersonal developmental dimensions connect to the cognitive dimensions such that personal agency from intrapersonal and interpersonal development can function as the foundation for self-directed learning with higher order thinking and selfregulation. Therefore, the phase of self-authorship achieves desirable learning outcomes in higher education.

\section{DEEPENING REFLECTION FROM DEVELOPMENTAL THEORY IN PROFESSIONAL EDUCATION}

The second theory relevant to improving the reflection process is derived from research in teacher education, which is a prominent research area in professional development alongside nursing research. Teacher education includes the topics of expertise, pedagogy, pedagogical content knowledge, teaching teacher, curriculum, reform, and policy (Loughran and Hamilton, 2016). In teacher training programs, research highlights how identity as a teacher develops (Korthagen et al., 2001; Olsen, 2008).

Identity development has external aspects of life experience, relationships and contexts, and internal aspects to the individual such as emotion. Self and identity share evolving processes over time, with the self as meaning maker and identity as meaning made (Rodgers and Scott, 2008). For professional development as teachers, their identity is continuously constructed through their lives as teachers and is central to their reflective practice of teaching (Korthagen, 2004).

Recently, assessment research on teacher identity has been started even though it is correlational analysis (Hanna et al., 2019, 2020). It revealed that the central factor of teacher identity was categorized as motivation, which has broad meanings including the intrinsic career value to teaching, satisfaction with teaching, self-evaluation of their work, and the desire to become a teacher. The theoretical framework of this survey research is the idea of identity-based motivation (Oyserman, 2008), wherein the motivation for becoming a teacher consists of the desire to become one and the possible selves theory (Hamman et al., 2010) wherein the extent to which one imagines being a teacher in the near future as the ideal self or future perspective influences the motivation for becoming a teacher (Zhang et al., 2016). A sense of identity involves continuity as accumulation of ongoing life experience and time perspectives on past, present and future.

Reflection assumes a key role in teacher identity development (Korthagen et al., 2001; Beauchamp and Thomas, 2009) and functions not only at the level of behavior and competencies but also at the level of identity and mission where they see why they are becoming teachers (Korthagen, 2004). In teacher development, the model of reflection process is called the ALACT model and it tells supervisors (teacherin-training instructors) how to intervene (Korthagen et al., 2001). The first phase of reflection is Action and supervisors help find useful experiences. Phase 2 is to Look back on that action, Phase 3 is to be Aware of the essential aspects of events and experiences, and Phase 4 is to Create alternative methods of action. Through these phases, supervisors support practitioners as follows: using acceptance and empathy, showing genuineness, focusing on concreteness of events, confronting discrepancy or contradiction between practitioners' thoughts and actions, generalizing beyond specific experiences, utilizing here-and-now experiences, and making things explicit. The final phase is Trial and supervisors help to continue the learning process.

This teacher reflection model works to deepen reflection acquiring core quality, which involves teachers' identity and mission (Korthagen and Vasalos, 2005). Without tapping into their identity, teachers slip into superficial and technical considerations about their teaching. The core reflection process sticks to clarifying what problems they encounter and contrasting present issues with their desired situations. The following phases is that teachers become aware of ideal situations, limitedness, and core qualities in looking back on experiences. Core reflection identifies external obstacles in contexts and environments, but also examines how one constructs oneself internally (Korthagen, 2014). It answers what one wants to achieve or create, how one prevents oneself (i.e., one's behavior, feeling, images and beliefs) from achieving them, and what core quality is needed to realize the ideal situation and overcome the limitations. After teachers embed themselves into situations, they move on to new situations and induce alternative methods from these reflections that mobilize their core qualities. Supervisors trust students' autonomy in the core reflection process and support their becoming aware of internal potential (Meijer et al., 2009).

This teacher reflection model probes the core reflection process involving teachers' selves, identities, and missions. Further research is needed to attempt to explain theoretically how the self relates to and develops in this process. Progress has been made by research from the theoretical perspective of the 
dialogical self (Hermans et al., 1992; Hermans and HermansKonopka, 2010; Akkerman and Meijer, 2011; Hermans and Gieser, 2011). Teacher identity development is an ongoing and dialogical process of negotiating, interrelating, and reconciling multiple selves through narrating (Akkerman and Meijer, 2011). Dialogical self-theory has established the multiplicity of self, which means the self as constituted by multiple Ipositions. Each I-position has a voice with its own viewpoint and conducts story-telling. A student, for example, could have the I who intends to socialize out of class, the I who struggles to get good grades in class, and the I who wants to build a professional career at work. The multiplicity of the self implies that an I-position cannot completely overwhelm and conquer other I-positions, but each I-position interplays at their juxtapositions. Through narrating and re-narrating (Clandinin and Rosiek, 2007) with supervisors' appropriate intervention, students can shift from conflictive confrontation, with contradiction and discontinuity, to harmonious reconciliation.

Teacher identity development involves resolving tensions between multiple beliefs from childhood, schooldays, and the workplace (Alsup, 2006). As suggested by this teacher reflection model, teachers strive to look back on their experiences and make sense of them by taking their students' perspectives and asking: what do they want, what do they do and think, and how they feel (Korthagen and Vasalos, 2005; Korthagen, 2014). There is discontinuity in teachers' identity development when they face the gap between their ideals and actual problems. Confronting problematic situations, the question of what is ideal facilitates their reflection, interrogates who they are at that moment, and illuminates what an ideal self as teacher would do. Core reflection scrutinizes both external situations and contexts and inward internal potentials and alternatives. Core reflection confronts the problem that previous I-positions were unaware of the source of conflict and that there was a discrepancy between the experienced self and the ideal self. In the ongoing process of daily teaching practice and narrating their experiences, teachers can reconcile the discrepancies in their continuous narrative by making or renewing Ipositions in some cases, or through clarifying the limits and obstacles of previous I-positions and teaching experiences. Based on these reconciliations, they can generalize lessons or beliefs from their experiences and try alternative methods of action.

Research based on the teacher reflection model confirms that the reflective process relates to a sense of identity by posing the question of who I am at that moment. Teacher identity development associated with dialogical self-theory sheds new light on this reflective process. As the constitutive developmental theory including self-authorship development explained above, the process of deepening reflection is the movement of subject to object. A subject is unaware of its I-position but after a new I-position is differentiated, the subject becomes an object. Through daily practice, confronting dissonance or contradiction invokes reflection and interplay between multiple I-positions. Reconciling them does not dispose of previous I-positions but creates co-existence at their juxtaposition with a resilient continuity and "the agency of self" (Hermans, 2011) for future practice.

\section{DEEPENING REFLECTION FROM IDENTITY DEVELOPMENT THEORY}

The third thread of theory is identity development theory. The discussion so far inquires how the reflection process reaches holistic identity development. This section examines comprehensive identity theory itself. Beyond the dichotomy of the personal and social dimensions of identity (Vignoles et al., 2011; Vignoles, 2018), recent identity theory synthesizes a model of triadic development grounded on both psychology and sociology (Côté and Levine, 2014; Côté, 2019).

Psychological theorization of identity consists of three levels of social, personal, and ego identity, four junctures between the levels and three principles of integration, differentiation, and continuity corresponding to each level. Social identity works in social structural contexts based on integration into the community and the broader society around it. Personal identity functions in the interaction that differentiates between the self and the other. Ego identity synthesizes the continuous experience of the personality process. These three levels identity do not work independently but are interconnected. The first juncture from social identity to personal identity is validation and challenge regarding to socialization, where social structure influences daily practice. The juncture from personal identity to ego identity is interpretation on one's identity which works as ego synthesis. Through this interpretation, meanings are internalized into the continuity of selves such as a personality. The juncture from ego identity to personal identity is strategic intentions for action which function as ego executives. This is self-presentation to daily interaction and is involved in action and practice. Finally, the juncture from personal identity to social identity is identity displays as collective activities which have, to some extent, effects on social structure contexts.

Sociological theory takes account of the contexts of identity development and cultural and historical conditions. Latemodern society influences the individualized life course, in which one develops one's self as an "individual," dissociating from collective supports and values (Giddens, 1991; Beck and BeckGernsheim, 2002). Youth development in the school to work transition has been influenced by this individualization and youth follow paths in the continuum between the default and developmental individualization (Côté and Levine, 2015).

A default individualization is produced by lack of engagement in deliberative decision making for action and a superficial perspective for the future. In the triadic model of identity development, it doesn't function at the level of ego identity, i.e., ego syntheses and ego executives, instead confusing or diffusing identities. Unless they engage intentionally in identity formation, continuity, the third principle of identity, promises nothing but default individualization. Conversely, people who pursue developmental individualization are involved in a proactive approach for identity formation. They engage in exploration 
and taking deliberate action for possible selves while broadening future perspectives and purposes. Continuity sets the space where time perspective extends from past to present and future through retrospective and prospective reflection. It also unfolds the movement of subject to object and dialogical interplays among I-positions. Purpose consists of present engagement and future life perspectives including these extending time perspectives, and so consolidates them and creates the function of agency (Emirbayer and Mische, 1998; Damon, 2008). Therefore, the triadic identity formation with integration, differentiation, and continuity can provide an individual's self-regulated agency based on intrapersonal dynamics, as discussed above, which is named identity-based agency (Côté and Levine, 2014, 2015; Côté, 2019).

Identity development provides the function of continuity to reflective practice, in addition to integration and differentiation. Reflective practice unfolds at the level of interaction related to personal identity. If reflective practice sticks to this level and does not involve the level of ego identity, it deadlocks and remains superficial. The triadic model of identity theory explains the conditions of deepening reflective practice by means of outward and inward exploration. Outward exploration is grounded upon integration in various social structures such as the community and the workplace. It also connects prosocial behavior with various others and empathic understanding of others' backgrounds. When outward exploration activates reciprocal inward exploration, reflection can deepen. Inward exploration accompanies the activation of purpose, which enriches future perspectives and fosters engagement with deliberate plans. This active exploration inward creates a proactive approach to identity development and identity-based agency at the three level of life course, interaction, and personality process. To deepen reflection is a continuous exercise of outward and inward identity-based agency at all three level of identity, resulting in developmental individualization for negotiating the transition from school to work.

\section{REVISITING HOW TO DEEPEN THE REFLECTIVE PROCESS IN SERVICE LEARNING}

Making the best use of service learning's potential, teachers can deepen students' critical reflection and promote identity development. Well-designed service learning as a high impact educational practice provides opportunities of interaction with diverse others including other students, community residents, and workers in the community service (Bringle et al., 2009). This is an opportunity in which students can encounter new ideas, views, backgrounds, intercultural diversities, and various social identities such as race, ethnicity, class, and gender. Thus, it is an opportunity for social experiences in which they can recognize the differences between suffering individuals and themselves, and also those between the professionals who are role models for students and themselves. Well-designed service learning can encourage civic identity development (Bringle et al., 2015). In service activities, there are ill-structured problems which lack a single right answer from an absolute external authority. These problems orient students to be aware of the deficiency of depending on external formula and help them find their internal voices toward self-authorship. Exposing new and different ideas from service experience in the community builds multiplicity and relativism in their intellectual development, leading to selfauthorship (Egart and Healy, 2004; Baxter Magolda and Boes, 2017). To contribute to the outcomes of service activities, each student needs to make their own ideas or take their roles collaboratively, questioning what they can do and who they are. Effective service learning, as survey research revealed (Astin et al., 2000; Celio et al., 2011), can generate cognitive and emotional outcomes only when students engage in service activities and deepen reflection on the experiences from these opportunities.

Not all reflection reaches the level of deep reflection to generate several outcomes. The theoretical explanation of the reflective process, as reviewed above, clarifies several conditions of deepening reflection, which help to elaborate the reflection models from service learning research. These conditions are also design principles for instructors to structure and facilitate students' deep reflection.

The first condition is to start with students' dissonances in service activities. Without specifying the experiences, their reflections produce vague, unfocused, and superficial descriptions. Dissonance is an effective starting point for reflection on concrete experience because it helps to remember the scene, behavior, thinking and feeling then-and-there. Focusing on concreteness is a guideline for describing experiences implied by the tearcher reflection model (Korthagen and Vasalos, 2005; Korthagen, 2017) as well as the reflection model in service learning (Ash and Clayton, 2009). Unless students describe what happens, reflection tends to remain abstract, and hence superficial. Reflection cannot deepen by investigating why something happens without describing what students experience.

The second condition of deepening reflection is to examine discrepancies emerging while describing dissonance in the concrete situations. Instructors should facilitate students' inquiries into discrepancies between actual situations and ideal ones by asking prompts which the reflection models adopt, rather than by providing an instructor's answer. Instructors should push students to reflect on service experience specifically, shifting meaning from uncertain to certain; in other words, they encourage movement from subject to object (Baxter Magolda and Boes, 2017). In this way, students can leave the phase of following external authority and head for constructing internal voices toward self-authorship (Baxter Magolda and King, 2012). Encouragement, however, does not guarantee realizing this movement or establishing an internal foundation for selfauthorship. To deepen reflection and make sense of situations, students must engage in inward and outward exploration.

It is essential for deepening reflection to involve in inward exploration through dialogical interplays among I-positions indicated by the dialogical self theory (Hermans and HermansKonopka, 2010; Hermans, 2011). Students cannot pursue these dialogues only by imagining them. A single voice in several positions generates only monolog. Only when each position has 
a voice would these multi-voiced dialogues begin. Even when multiple stakeholders collaborate effectively in service learning, students face practical, technical or ethical contradictions in the middle of solving problems and achieving goals. From the viewpoints of students, the I-position as a student hesitates to invest more time and effort than expected to get a good grade, but the I-position as a worker in community service feels irritated by the insufficient contribution of other co-workers. Students cannot necessarily solve and reconcile contradictions among Ipositions by themselves. They may oversee potential I-positions for activating dialogue among I-positions. Instructors must force students to confront contradictions among their I-positions and encourage their reconciliation.

Outward exploration in the interpersonal dimension is required to activate dialogical interplays among I-positions through inward exploration in the intrapersonal dimension. Well-designed service learning with multiple partnerships prepares an opportunity for interaction with diverse others expanding students' empathy (Hoffman, 2010; Bringle, 2017). To learn fully from these interactions, students should be reflective meaning-makers and engage in further outward exploration. Through it, they must find and identify other people's multiple I-positions just as they are discovering the multiplicity of their own selves. For example, a community worker may have not only a worker I-position but also a parent I-position, a husband Iposition, and a immigrant I-position; furthermore, each position has its own voice. It is essential for students to recognize that a person does not have a united monologuing voice, but multiple voices, and perhaps contradictions among his or her I-positions. Therefore, the third requirement of deepening reflection is to confront and reconcile contradictions among I-positions by dialogical interplays and juxtapositions of multiple I-positions from both sides of students' own and others' I-positions.

Instructors should teach students to recognize others' multiplicity as well as the multiplicity among their own Ipositions by asking questions with an appropriate balance of support and challenge. The questions include who they are at that moment, what they feel and think then-and-there, what other people do then-and-there, and how they interpret those experiences from the perspective of now-and-here. These questions as prompts facilitate describing their own selves in the situations. Instructors push students to be aware of ideal situations, behavior, and thinking by making use of previous students' or professionals' experiences. These ideals are not the only right answers but alternatives for students' interpretation toward betterment and future action. In this way, skilled instructors should confront students with these contradictions in the process of differentiating the voice of each I-position, making new I-positions sometimes, and reconciling them through the dialogue of their different voices.

Meeting the three conditions above enriches the description of experience and dialogical spaces. Thus, students can examine their experience more critically and deeply compared with the case of superficial descriptions. It expands time perspectives both retrospectively and prospectively. Retrospective expansion of reflection inquires beyond what happened to why it happened. It's the movement of here-and-now to then-and-there. The inquiry investigates not only situations but also students themselves by asking why they did so, felt so, said so, thought so and so on. When they reflect beyond who they were at that moment to why they were so, retrospective inquiry digs back before the experience emerged. Through it, students should confront their prejudice, misunderstanding and patronization by asking how they obstructed themselves and how they constructed themselves. It means finding the discontinuity between the previous, present, and future I-positions and the discrepancies between the actual selves, ideal selves and possible selves. Students often brought their prejudices into service activities, producing unpleasant experience for themselves and stakeholders. They cannot necessarily recognize and solve this problem by themselves. Instructors must make students aware of what and why it happened and ask them to reflect on their prejudices. Because service and learning are a recursive process, skilled instructors should guide students to connect future trial action prospectively in the relationship with the same stakeholders in the same community. Furthermore, from the theorization that active engagement activates purpose in life for the future (Damon, 2008; Bronk, 2013), instructors should encourage students to connect their experience in service learning to reconstruct life purpose.

Students can enhance the quality of deep reflection by persisting in the process of service and learning. One-timeonly reflection cannot deepen; the accumulation of making meaning is a necessary condition of deepening reflection. The teacher reflection model showed that technical or practical problem experienced by students can be solved by means of alternative approaches based on the awareness of multiple aspects of experiences and situations (Korthagen et al., 2001; Korthagen, 2017). Likewise, ethical contradictions generate discontinuity between the previous, present, and future Ipositions. Reconciling contradictions requires changing the configuration of I-positions with perspective transformation. This reconciling process is a transformative learning process (Mezirow, 1991, 2018; Taylor, 2017). It means that transforming self-identity is identity development. In this way, well-designed service learning provides these continuous processes that sustains the proactive approach for identity formation, which involves future purpose in life and action with exploration of possible self and identities (Côté and Levine, 2014; Kawai and Moran, 2017; Côté, 2019). Reconciling those contradictions can be realized by extending the dialogical space with multi-voiced juxtapositions of I-positions and expanding the time perspective both retrospectively and prospectively. Thus, it creates agency of self (Hermans, 2011) and identity-based agency (Côté and Levine, 2014, 2015; Côté, 2019).

This process also does not necessarily occur. The fourth condition of deepening reflection is to expand its time perspective retrospectively and prospectively, thereby bridging the discontinuities in several relationships. Those are relationships between service experiences and academic knowledge, between past, present, and future selves, and between individuals and society. Instructors must accompany students' persistent reflection and intervene continuously, retracing their past reflection for accumulated meaning making. Therefore, 
journal writing is an effective way of deepening reflection for students and instructors as the DEAL and the ALACT models emphasize (Ash and Clayton, 2009; Korthagen, 2017). Because writing functions as an applied meta cognition (Hacker et al., 2009), writing with reply to the above questions should be expected to facilitate movement from subject to object of experience toward self-authorship, to foster the juxtapositions of their own and others' differentiated I-positions, and to expand time perspective retrospectively and prospectively.

Instructors' feedback on reflective writing and inquiry in conversation should confront students with the questions discussed above. Instructors should also require students to apply academic concepts in the context of service activities so that the shifts occur from uncritical acceptance of academic concepts to critical understanding bridged their own experiences (Kawai, 2012; Kawai and Mizokami, 2013; Kawai and Kimura, 2014). Critical understanding of academic concepts means being aware of their limits. This academic enhancement in the cognitive dimension promotes students' interpersonal development from the relationships with familiar others such as friends to relationships with distant others, i.e., those with different backgrounds and cultures, groups which they have not met, and society as a whole. Furthermore, when critical examination on the source of their own prejudice in intrapersonal dimension connects to this academic enhancement, it moves forward to probe the influence of social structure critically, such as social norms and social assumptions which are taken for granted. Instructors must encourage students to think about the effects of social structures as objects and reinterpret the plurality of social norms and values, finding possible alternatives. Seeing social structures as objects and executing identity-based agency enables, if necessary, resisting the oppression of such contexts. When students achieve deep recognition of themselves and social contexts and acquire capabilities for civic engagement, they can contribute to social action. In some cases, they can even construct social entrepreneurship actions such as collective activities, which are a contribution to constitution of society. By making the best use of the educational benefits of service learning, students can transform from passive receptors supported by multiple stakeholders to active constructors engaging civically in collective activities to influence the constitution of society.

Expanding perspectives from individual development to the relationship among individuals, the community and society activates mutuality between them, which is a central principle of sense of identity formulated by Erikson (1968). He wrote about mutuality between a family and infant, "A family can bring up a baby only by being brought up by him [sic]" (Erikson, 1968, p. 96). Mutuality means reciprocal relationships, which is core character of service learning (Bringle and Clayton, 2012). His insights expand that mutuality to several relationships: individual and community, and individual and society. Community and society can recognize students' identity and provide energy for their identity formation only by being recognized for their civic engagement. He named the mutual relationship between preceding and succeeding generations as generativity. Mutuality works in generativity in the relationship between preceding and succeeding generations, which is a typical partnership in community service learning.
Regarding youth development, the generativity supports intergenerational activation and, for a democratic society, mutual involvement through generativity must resist fragmenting into individualism (Côté, 2019). Therefore, contemporary society requires generative collaboration and solidarity against discrepancy and oppression. Service learning, as civic-minded graduate models show (Bringle, 2017; Bringle et al., 2019; Bringle and Wall, 2020), requires students to care about diverse others and pursue social interests through deliberative democratic dialogue toward ethical generativity. It is essential for individual development to sustain inward and outward dialogue in the three dimensions of cognitive, intrapersonal, and interpersonal. For the relationships among citizens, communities, and society, deliberative democratic dialogue is indispensable to mutual activation of ethical generativity with solidarity against intolerance and hostility.

\section{CONCLUSION}

Service learning research has revealed that well-designed service learning generates academic, civic, and personal outcomes through reflection. This paper is based on these findings and provides an expanded theoretical explanation regarding how to deepen reflection, incorporating student development theory, professional development theory, and identity development theory. It reveals the conditions for deepening the student reflection process in service learning. Instructors guide students to focus on dissonance in concrete experiences and to find and describe discrepancies in differences of views or backgrounds between those of students and others. It is not until deep reflection is achieved that students engage in outward exploration of those differences and inward exploration that leads to the construction of internal voices toward self-authorship. Instructors must also resist stopping at a superficial understanding of contradictions from these explorations. Instead, they should force students to confront contradictions through dialogical interplays among their Ipositions and those of others in order to understand their multiplicity and complexity. This confrontation also means that students should become aware of contradictions embedded in their prejudices and discontinuities between their past, present, and future selves through the expansion of the time perspective both retrospectively and prospectively. Furthermore, instructors must encourage students to reconcile contradictions and bridge these discontinuities by appreciating the multiplicity and plurality in others' views and social norms. Deepening reflection in service learning can activate mutuality between students and community, and generativity between preceding and succeeding generations toward solidarity.

This theoretical explanation of deepening reflection contributes to the understanding of the potentials of service learning. However, this explanation is based on selected sources from three theoretical threads. Further theoretical work should incorporate other competing theories in service learning. It also requires investigation into the factors that cause reflection to remain superficial and the conditions that cause reflection to enforce students' prejudices. These investigations should involve empirical research and generate evidence. 
Theoretical explanations provide ideas and frameworks for this kind of empirical research focusing on specific factors such as dissonance in students' experience, discrepancies between differences, and dialogue for the reconciliation of the contradictions.

\section{AUTHOR CONTRIBUTIONS}

TK: conception, design of study, and writing a paper.

\section{REFERENCES}

AAC and U (Association of American Colleges and Universities). (2007). College Learning for the New Global Century: A Report from the National Leadership Council for Liberal Education and America's Promise. Washington, DC: Association of American Colleges and Universities.

Akkerman, S. F., and Meijer, P. C. (2011). A dialogical approach to conceptualizing teacher identity. Teach. Teach. Educ. 27, 308-319. doi: $10.1016 /$ j.tate.2010.08.013

Alsup, J. (2006). Teacher Identity Discourses: Negotiating Personal and Professional Spaces. Mahwah, NJ: Lawrence Erlbaum.

Ambrose, S. A., Bridges, M. W., DiPietro, M., Lovett, M. C., and Norman, M. K. (2010). How Learning Works: Seven Research-Based Principles for Smart Teaching. San Francisco, CA: John Wiley \& Sons.

Anderson, L. W., and Krathwohl, D. R. (2001). A Revision of Bloom's Taxonomy of Educational Objectives. A Taxonomy for Learning, Teaching and Assessing. New York, NY: Addison-Wesley Longman.

Ash, S. L., Clayton, P. H., and Moses, M. G. (2009). Learning through Critical Reflection: A Tutorial for Service-Learning Students. Sterling, VA: Stylus.

Ash, S. L., and Clayton, P. H. (2009). Generating, deepening, and documenting learning: the power of critical reflection in applied learning. J. Appl. Learn. High. Educ. 1, 25-48.

Astin, A. W., Vogelgesang, L. J., Ikeda, E. K., and Yee, J. A. (2000). How Service Learning Affects Students. Los Angeles, CA: Higher Education Research Institute, University of California.

Barber, J. P., and King, P. M. (2014). Pathways toward self-authorship: student responses to the demands of developmentally effective experiences. J. Coll. Stud. Dev. 55, 433-450. doi: 10.1353/csd.2014.0047

Bateson, G. (2000). Steps to an Ecology of Mind: Collected Essays in Anthropology, Psychiatry, Evolution, and Epistemology. Chicago: University of Chicago Press.

Baxter Magolda, M. B. (2001). Making Their Own Way: Narratives for Transforming Higher Education to Promote Self-Development. Sterling, VA: Stylus.

Baxter Magolda, M. B. (2004). Evolution of a constructivist conceptualization of epistemological reflection. Educational Psychologist 39, 31-42. doi: 10.1207/s15326985ep3901_4

Baxter Magolda, M. B. (2007). Self-authorship: The foundation for twentyfirst-century education. New Dir. Teach. Learn. 109, 69-83. doi: 10.1002/ tl.266

Baxter Magolda, M. B. (2009). Authoring your Life: Developing an Internal Voice to Navigate Life's Challenges. Sterling, VA: Stylus.

Baxter Magolda, M. B., and Boes, L. M. (2017). "Educational theory and student civic outcomes," in Research on Student Civic Outcomes in Service Learning: Conceptual Frameworks and Methods, eds. J. A. Hatcher, R. G. Bringle, and T. W. Hahan (Sterling, VA: Stylus), 115-133.

Baxter Magolda, M. B., and King, P. M. (eds.). (2012). Assessing meaning making and self-authorship: theory, research, and application. ASHE Higher Educ. Rep. 38, 1-138. doi: 10.1002/aehe.v38.3

Baxter-Magolda, M. B. (1992). Knowing and Reasoning in College: Gender-Related Patterns in Students' Intellectual Development. San Francisco, CA: Jossey-Bass.

Beauchamp, C., and Thomas, L. (2009). Understanding teacher identity: An overview of issues in the literature and implications for teacher education. Camb. J. Educ. 39, 175-189. doi: 10.1080/03057640902902252

Beck, U., and Beck-Gernsheim, E. (2002). Individualization: Institutionalized Individualism and its Social and Political Consequences. London: Sage Publications.

\section{FUNDING}

This work was supported by Japan Society for the Promotion of Science, Grants-in-Aid for Scientific Research, JAPAN, 18K13198.

\section{ACKNOWLEDGMENTS}

I am grateful to R. G. Bringle for advice on this research.

Benner, P., Tanner, C., and Chesla, C. (eds.). (2009). Expertise in Nursing Practice: Caring, Clinical Judgment, and Ethics, 2nd Edn. New York, NY: Springer Publishing Company.

Bringle, R. G., Clayton, P. H., and Price, M. (2009). Partnerships in service learning and civic engagement. Partnerships J. Serv. Learn. Civic Engag. 1, 1-12.

Bringle, R. G. (2017). “Social psychology and student civic outcomes”, in Research on Student Civic Outcomes in Service Learning: Conceptual Frameworks and Methods, eds J. A. Hatcher, R. G. Bringle, and T. W. Hahan (Sterling, VA: Stylus), 69-89.

Bringle, R. G., Clayton, P. H., and Bringle, K. E. (2015). From teaching democratic thinking to developing democratic civic identity. Partnerships J. Serv. Learn. Civic Engag. 6, 51-76.

Bringle, R. G., Hahn, T. W., and Hatcher, J. A. (2019). Civic-minded graduate: additional evidence II. Int. J. Research on Serv. Learn. Commun. Engage. 7:3. doi: 10.37333/001c.11481

Bringle, R. G., and Clayton, P. H. (2012). "Civic education through service learning: what, how, and why?," in Higher Education and Civic Engagement, eds. L. McIlrath, A. Lyons, and R. Munck (New York, NY: Palgrave Macmillan), 101-124.

Bringle, R. G., and Wall, E. (2020). Civic-minded graduate: additional evidence. Michigan J. Community Serv. Learn. 26, 1-18. doi: 10.3998/mjcsloa.3239521.0026.101

Bronk, K. C. (2013). Purpose in Life: A Critical Component of Optimal Youth Development. New York, NY: Springer.

Côté, J. E. (2019). Youth Development in Identity Societies: Paradoxes of Purpose. New York, NY: Routledge.

Côté, J. E., and Levine, C. G. (2014). Identity, Formation, Agency, and Culture: A Social Psychological Synthesis. New York, NY: Psychology Press.

Côté, J. E., and Levine, C. (2015). Identity Formation, Youth, and Development: A Simplified Approach. New York, NY: Psychology Press.

Celio, C. I., Durlak, J., and Dymnicki, A. (2011). A meta-analysis of the impact of service-learning on students. J. Exp. Edu. 34, 164-181. doi: 10.5193/JEE34.2.164

Chickering, A. W., and Reisser, L. (1993). Education and Identity. The Jossey-Bass Higher and adult Education series. San Francisco, CA: Jossey-Bass.

Clandinin, D. J., and Rosiek, J. (2007). "Mapping a landscape of narrative inquiry," in Handbook of Narrative Inquiry: Mapping a Methodology, ed D. J. Clandinin (Sage Publications), 35-75.

Conway, J. M., Amel, E. L., and Gerwien, D. P. (2009). Teaching and learning in the social context: a meta-analysis of service learning's effects on academic, personal, social, and citizenship outcomes. Teach. Psychol. 26, 233-245. doi: 10.1080/00986280903172969

Damon, W. (2008). The Path to Purpose: Helping our Children Find their Calling in Life. New York, NY: Free Press.

Egart, K., and Healy, M. P. (2004). "An urban leadership internship program," in Learning Partnerships: Theory and Models of Practice to Educate for Self-Authorship, eds M. B. Baxter Magolda and P. M. King (Sterling, VA: Stylus), 125-150.

Emirbayer, M., and Mische, A. (1998). What is agency? Am. J. Sociol. 103, 962-1023. doi: 10.1086/231294

Erikson, E. H. (1968). Identity: Youth and Crisis. New York, NY: Norton.

Evans, N., Forney, D., Guido, F., Patton, L., and Renn, K. (2009a). Student Development in College: Theory, Research, and Practice, 2nd Edn. San Francisco, CA: Jossey-Bass.

Evans, N., Forney, D., Guido, F., Patton, L., and Renn, K. (2009b). Perry's Theory of Intellectual and Ethical Development. Student Development in College: Theory, Research, and Practice, 2nd Edn. San Francisco, CA: Jossey-Bass, 82-98. 
Eyler, J., and Giles Jr, D. E. (1999). Where's the Learning in Service-Learning? San Francisco, CA: Jossey-Bass.

Gelmon, S. B., Holland, B. A., and Spring, A. (2018). Assessing Service-Learning and Civic Engagement: Principles and Techniques. Stylus Publishing, LLC.

Giddens, A. (1991). Modernity and Self-Identity: Self and Society in the Late Modern Age. Stanford, CA: Stanford university press.

Hacker, D. J., Keener, M. C., and Kircher, J. C. (2009). "Writing is applied metacognition," in Handbook of Metacognition in Education, eds. D. J. Hacker, J. Dunlosky, and A. C. Graesser (New York, NY: Routledge), 154-172.

Hamman, D., Gosselin, K., Romano, J., and Bunuan, R. (2010). Using possible-selves theory to understand the identity development of new teachers. Teach. Teach. Educ. 26, 1349-1361. doi: 10.1016/j.tate.2010. 03.005

Hanna, F., Oostdam, R., Severiens, S. E., and Zijlstra, B. J. (2019). Domains of teacher identity: a review of quantitative measurement instruments. Educ. Res. Rev. 27, 15-27. doi: 10.1016/j.edurev.2019.01.003

Hanna, F., Oostdam, R., Severiens, S. E., and Zijlstra, B. J. (2020). Assessing the professional identity of primary student teachers: design and validation of the teacher identity measurement scale. Stud. Educ. Eval. 64:100822. doi: 10.1016/j.stueduc.2019.100822

Hatcher, J. A., and Bringle, R. G. (1997). Reflection: bridging the gap between service and learning. Coll. Teach. 45, 153-158. doi: $10.1080 / 87567559709596221$

Hermans, H., and Hermans-Konopka, A. (2010). Dialogical Self Theory: Positioning and Counter-Positioning in a Globalizing Society. Cambridge University Press.

Hermans, H. J., Kempen, H. J., and Van Loon, R. J. (1992). The dialogical self: beyond individualism and rationalism. Am. Psychol. 47, 23-33. doi: 10.1037/0003-066X.47.1.23

Hermans, H. J. M. (2011). "The dialogical self: a process of positioning in space and time," in The Oxford Handbook of the Self, ed S. Gallagher (New York, NY: Oxford University Press), 654-680.

Hermans, H. J. M., and Gieser, T. (eds.). (2011). Handbook of Dialogical Self Theory. New York, NY: Cambridge University Press

Hoffman, M. L. (2010). "Empathy and prosocial behavior," in Handbook of Emotions, $3 r d$ Edn, eds. M. Lewis, J. M. Haviland-Jones, and L. F. Barrett (New York, NY: Guilford Press), 440-455.

Jameson, J. K., Clayton, P. H., and Ash, S. L. (2013). "Conceptualizing, assessing, and investigating academic learning in service learning," in Research on Service Learning: Conceptual Frameworks and Assessment, Vol. 2A, eds P. H. Clayton, R. G. Bringle, and J. A. Hatcher (Sterling, VA: Stylus), 85-110.

Jones, S. R., and Abes, E. S. (2013). Identity Development of College Students: Advancing Frameworks for Multiple Dimensions of Identity. San Francisco, CA: John Wiley \& Sons.

Kawai, T. (2012). The impact of participation in out-of-class communities of practice and bridge learning on student learning and development. Educ. Tech. Res. 35, 135-144. doi: 10.15077/etr.KJ00008327918

Kawai, T., and Kimura, M. (2014). A study on the role of reflection and bridge learning in service-learning: through the survey of the "community service learning" course at ritsumeikan university. Educ. Tech. Res. 37, 15-23. doi: $10.1002 /$ cc.20089

Kawai, T., and Mizokami, S. (2013). Analysis of bridge learning: focus on the relationship between bridge learning, approaches to learning, and the connection of present and future life. Educ. Tech. Res. 36, 23-31. doi: 10.15077/etr.KJ00008877023

Kawai, T., and Moran, S. (2017). How do future life perspective and present action work in Japanese youth development? J. Moral. Educ. 46, 323-336. doi: 10.1080/03057240.2017.1350150

Kegan, R. (1982). The Evolving Self. Cambridge, MA: Harvard University Press.

Kegan, R. (1994). In Over Our Heads: The Mental Demands of Modern Life. Cambridge, MA: Harvard University Press.

Kegan, R., and Lahey, L. (2009). Immunity to Change: How to Overcome it and Unlock Potential in Yourself and Your Organization. Boston, MA: Harvard Business Press.

King, P. M., and Kitchener, K. S. (1994). Developing Reflective Judgment: Understanding and Promoting Intellectual Growth and Critical Thinking in Adolescents and Adults. San Francisco, CA: Jossey-Bass.
King, P. M., and Kitchener, K. S. (2004). Reflective judgment: theory and research on the development of epistemic assumptions through adulthood. Educ. Psychol. 39, 5-18. doi: 10.1207/s15326985ep3901_2

Korthagen, F., and Vasalos, A. (2005). Levels in reflection: Core reflection as a means to enhance professional growth. Teach. Teach. Theory Pract. 11, 47-71. doi: 10.1080/1354060042000337093

Korthagen, F. A. (2004). In search of the essence of a good teacher: towards a more holistic approach in teacher education. Teach. Teach. Educ. 20, 77-97. doi: $10.1016 / j$. tate.2003.10.002

Korthagen, F. A. (2014). "Promoting core reflection in teacher education: deepening professional growth," in International Teacher Education: Promising Pedagogies, eds. L. Orland-Barak, and C. J. Craig (Bingley, UK: Emerald Group Publishing Limited), 73-89.

Korthagen, F. A. (2017). "A foundation for effective teacher education: teacher education pedagogy based on situated learning," in The SAGE Handbook of Research on Teacher Education, eds. D. J. Clandinin, and J. Husu (Los Angeles, CA: Sage), 528-544.

Korthagen, F. A., Kessels, J., Koster, B., Lagerwerf, B., and Wubbels, T. (2001). Linking Practice and Theory: The Pedagogy of Realistic Teacher Education. Lawrence Erlbaum Associates Publishers.

Kuh, G. D. (2008). High-Impact Educational Practices: What They Are, Who has Access to Them, and Why they Matter. Washington, DC: AAC.

Loughran, J., and Hamilton, M. L. (eds.). (2016). "Developing an understanding of teacher education," in International Handbook of Teacher Education, eds J. Loughran, and M. L. Hamilton (New York, NY: Springer).

Love, P. G., and Guthrie, V. L. (1999). Understanding and applying cognitive development theory: new directions for student services. San Francisco, CA: John Wiley \& Sons.

McCormick, A. C., Kinzie, J., and Gonyea, R. M. (2013). "Student engagement: Bridging research and practice to improve the quality of undergraduate education," in Higher Education: Handbook of Theory and Research, ed M. B. Paulsen (Dordrecht: Springer), 47-92.

Meijer, P. C., Korthagen, F. A., and Vasalos, A. (2009). Supporting presence in teacher education: The connection between the personal and professional aspects of teaching. Teach. Teach. Educ. 25, 297-308. doi: $10.1016 /$ j.tate.2008.09.013

Mezirow, J. (1991). Transformative Dimensions of Adult Learning. San Francisco, CA: Jossey-Bass.

Mezirow, J. (2018). "Transformative learning theory," in Contemporary Theories of Learning, ed K. Illeris (Routledge), 114-128.

Nilson, L. (2013). Creating Self-Regulated Learners: Strategies to Strengthen Students? Self-Awareness and Learning Skills. (Sterling, VA: Stylus).

Olsen, B. (2008). Teaching What They Learn, Learning What They Live: How Teachers' Personal Histories Shape their Professional Development. Boulder, CO: Paradigm Publishers.

Oyserman, D. (2008). Identity-based motivation and consumer behavior. J. Consum. Psychol. 19, 276-279. doi: 10.1016/j.jcps.2009.06.001

Patton, L. D., Renn, K. A., Guido, F. M., and Quaye, S. J. (2016). Student Development in College: Theory, Research, and Practice, 3rd Edn. San Francisco, CA: John Wiley \& Sons.

Paul, R., and Elder, L. (2001). The Miniature Guide to Critical Thinking Concepts and Tools. Santa Rosa, CA: Foundation for Critical Thinking.

Perry, W.G. Jr. (1968). Forms of Intellectual and Ethical Development in the College Years: A Scheme. New York,NY: Holt, Rinehart, \& Winston.

Pizzolato, J. E. (2007). Assessing self-authorship. New Dir. Teach. Learn. 109, 31-42. doi: 10.1002/tl.263

Rodgers, C. R., and Scott, K. H. (2008).” The development of the personal self and professional identity in learning to teach," in Handbook of Research on Teacher Education: Enduring Questions in Changing Contexts, eds. M. CochranSmith, S. Feiman-Nemser, D. J. McIntyre, and K. E. Demers (New York, NY: Routledge), 732-755.

Schön, D. A. (1983). The Reflective Practitioner: How Professionals Think in Action. New York, NY: Basic books.

Schwartz, S. J., Luyckx, K., and Vignoles, V. L. (eds.). (2011). Handbook of Identity Theory and Research. New York, NY: Springer Science \& Business Media.

Taylor, E. W. (2017). "Transformative learning theory," in International Issues in Adult Education: Transformative Learning Meets Bildung, eds. 
A. Laros, T. Fuhr, and E. W. Taylor (Boston, MA: Sense Publishing), 17-29.

Vignoles, V. L. (2018). "Identity: personal and social," in Oxford Handbook of Personality and Social Psychology, 2nd Edn, eds. K. Deaux and M. Snyder. (Oxford, UK: Oxford University Press), 289-315.

Vignoles, V. L., Schwartz, S. J., and Luyckx, K. (2011). "Introduction: toward an integrative view of identity," in Handbook of Identity Theory and Research, eds. S. J. Schwartz, K. Luyckx, and V. L. Vignoles (New York, NY: Springer), 1-27.

Whitley, M. A. (2014). A draft conceptual framework of relevant theories to inform future rigorous research on student service-learning outcomes. Michigan J. Commun. Serv. Learn. 20, 19-40. Available online at: http://hdl.handle.net/ 2027/spo.3239521.0020.202

Whitney, B. C., and Clayton, P. H. (2011). "Research on and through reflection in international service learning," in International Service Learning: Conceptual Frameworks and Research, eds. R. G. Bringle, J. A. Hatcher, and S. G. Jones (Sterling, VA: Stylus Publishing), 145-187.
Zhang, Y., Hawk, S. T., Zhang, X., and Zhao, H. (2016). Chinese preservice teachers' professional identity links with education program performance: the roles of task value belief and learning motivations. Front. Psychol. 7:573. doi: 10.3389/fpsyg.2016.00573

Conflict of Interest: The author declares that the research was conducted in the absence of any commercial or financial relationships that could be construed as a potential conflict of interest.

Copyright (c) 2021 Kawai. This is an open-access article distributed under the terms of the Creative Commons Attribution License (CC BY). The use, distribution or reproduction in other forums is permitted, provided the original author(s) and the copyright owner(s) are credited and that the original publication in this journal is cited, in accordance with accepted academic practice. No use, distribution or reproduction is permitted which does not comply with these terms. 